\title{
Acute kidney injury in liver cirrhosis: new definition and application
}

\author{
Florence Wong \\ Division of Gastroenterology, Department of Medicine, University of Toronto, Ontario, Canada
}

The traditional diagnostic criteria of renal dysfunction in cirrhosis are a $50 \%$ increase in serum creatinine (SCr) with a final value above $1.5 \mathrm{mg} / \mathrm{dL}$. This means that patients with milder degrees of renal dysfunction are not being diagnosed, and therefore not offered timely treatment. The International Ascites Club in 2015 adapted the term acute kidney injury (AKI) to represent acute renal dysfunction in cirrhosis, and defined it by an increase in $\mathrm{SCr}$ of $0.3 \mathrm{mg} / \mathrm{dL}(26.4 \mu \mathrm{moL} / \mathrm{L})$ in $<48$ hours, or a $50 \%$ increase in $\mathrm{SCr}$ from a baseline within $\leq 3$ months. The severity of AKI is described by stages, with stage 1 represented by these minimal changes, while stages 2 and 3 AKI by 2-fold and 3-fold increases in SCr respectively. Hepatorenal syndrome (HRS), renamed AKI-HRS, is defined by stage 2 or 3 AKI that fulfils all other diagnostic criteria of HRS. Various studies in the past few years have indicated that these new diagnostic criteria are valid in the prediction of prognosis for patients with cirrhosis and AKI. The future in AKI diagnosis may include further refinements such as inclusion of biomarkers that can identify susceptibility for AKI, differentiating the various prototypes of AKI, or track its progression. (Clin Mol Hepatol 2016;22:415-422)

Keywords: Hepatorenal syndrome; Ascites; Renal dysfunction; Treatment

\section{INTRODUCTION}

Renal dysfunction is a common complication of liver cirrhosis. This may be related to the abnormal hemodynamics of systemic and splanchnic arterial vasodilatation and extra-hepatic vasoconstriction peculiar to advanced cirrhosis.' This is termed functional renal failure, as the renal dysfunction is the result of relative renal ischemia, and is usually reversible upon correction of the hemodynamic abnormalities without any residual structural damage. However, many liver conditions are also associated with their distinctive renal problems. For example, patients with alcoholic cirrhosis are susceptible to the development of IgA nephropathy; patients with viral hepatitis $C$ frequently have cryoglobulinemia leading to renal damage. In addition, many systemic conditions such as vasculitis can affect both the liver and the kidney together, causing simultaneous liver and kidney injuries and dysfunction in both organs. ${ }^{2}$ Thus, patients with liver disease can frequently present with renal dysfunction and this could be acute in onset or gradual in its presentation, ultimately leading to a steady decline in renal function or chronic renal failure.

\section{THE CONCEPT OF AKI- WHY THERE IS A NEED FOR CHANGE}

Traditionally, renal failure in cirrhosis is defined as a $50 \%$ in-

\footnotetext{
Abbreviations:

ADQI, Acute Dialysis Quality Initiative; AKI, acute kidney injury; AKIN, Acute Kidney Injury Network; ATN, acute tubular necrosis; HRS, hepatorenal syndrome; IAC, International Ascites Club; IL-18, interleukin-18; KDIGO, Kidney Disease Improving Global Outcome; KIM-1, kidney injury molecule-1; L-FABP, liver type fatty acid binding protein; NGAL, neutrophil gelatinase-associated lipocalin; RIFLE, Risk Injury Failure Loss of renal function, End-stage renal failure; $\mathrm{SCr}$, serum creatinine
}

\author{
Corresponding author : Florence Wong \\ Division of Gastroenterology, Department of Medicine, University of \\ Toronto, 9th floor, Eaton Wing, Room 222, Toronto General Hospital, 200 \\ Elizabeth Street, Toronto. Ontario M5G2C4, Canada \\ Tel: +1-416-340 3834, Fax: +1-416-340 5019 \\ Email: florence.wong@utoronto.ca
}


crease in the serum creatinine $(\mathrm{SCr})$, with the final $\mathrm{SCr}$ being greater than $1.5 \mathrm{mg} / \mathrm{dL}(133 \mu \mathrm{mol} / \mathrm{L})$. $^{3}$ The use of this definition has proven to be very useful in the prognostication of patients with liver cirrhosis and decompensation. ${ }^{4,5}$ However, patients with decompensated cirrhosis and ascites have significant muscle wasting. Since creatinine is derived from creatine, which is mainly found in skeletal muscles, $\mathrm{SCr}$ may be low despite significant reduction in glomerular filtration because of poor creatinine biosynthesis from reduced muscle mass in these patients. ${ }^{6}$ Therefore, to reach a $\mathrm{SCr}$ of $1.5 \mathrm{mg} / \mathrm{dL}$ (133 $\mu \mathrm{mL} / \mathrm{L}$ ) in order to diagnose renal failure in cirrhosis means that many patients with milder degrees of renal dysfunction may be overlooked. It then follows that this threshold of $\mathrm{SCr}$ may represent a degree of renal dysfunction that is too advanced for treatments to be effective. This is especially true for patients with acute renal failure, who may not have the time to wait for the strict diagnostic criteria of renal failure to be reached before intervention can begin. Therefore, there is a need to change the definition of acute renal failure, especially since smaller changes in $\mathrm{SCr}$ in other patient populations seem to infer a negative impact on their survival. ${ }^{7}$

Various academic nephrology societies have proposed the concept of acute kidney injury (AKI) to represent acute changes in renal function. This includes minor changes in renal function that would not be recognized as renal failure. However, these minor changes may lead to permanent structural damage to the kidney, hence the term "injury" is preferred. The diagnostic criteria include a combination of glomerular filtration changes as well as reduction in urine output. Over the past decade, the definition of AKI has evolved through the Risk, Injury, Failure, Loss of function and End-stage renal failure or RIFLE criteria; ${ }^{8}$ the Acute Kidney Injury Network or AKIN criteria; ${ }^{9}$ and Kidney
Disease Improving Global Outcome or KDIGO criteria. ${ }^{10}$ The latest set of diagnostic criteria set forth not only the parameters for the diagnosis of AKI, but also defines various stages of AKI to document the severity of the condition.

\section{THE INTERNATIONAL ASCITES CLUB'S DEFI- NITION OF AKI}

A combined effort of researchers and academics from the International Ascites Club (IAC) representing the hepatology community, together with the Acute Dialysis Quality Initiative (ADQI), a nephrology community, finally decided in 2010 to adopt the nomenclature of AKI to represent acute renal failure in cirrhosis. The diagnostic criteria, however, were modified from the AKIN criteria for the cirrhotic patients. The use of a reduction in urine output as part of the diagnostic criteria was eliminated because cirrhotic patients with ascites frequently have a low urine output as part of their sodium and water retention syndrome. Many of these patients have a daily urine output of $<500 \mathrm{~mL} /$ day, which is already below the diagnostic criteria for the diagnosis of $\mathrm{AKI}$, and yet their glomerular filtration is near normal. Therefore, only the changes in $\mathrm{SCr}$ criteria are now used to diagnose AKI in cirrhosis. An acute increase in $\mathrm{SCr}$ by more than $3 \mathrm{mg} / \mathrm{dL}(26.5 \mu \mathrm{moL} / \mathrm{L})$ in less than 48 hours, or a 50\% increase in $\mathrm{SCr}$ from baseline represents a diagnosis of AKI. ${ }^{11}$ The IAC further fine-tuned the AKI diagnostic criteria (Table 1). ${ }^{12}$ The baseline $\mathrm{SCr}$ is now defined as a stable $\mathrm{SCr}$ that is available within the previous 3 months. When $\mathrm{SCr}$ is not available, then the $\mathrm{SCr}$ that is closest to the current $\mathrm{SCr}$ is used. When $\mathrm{SCr}$ measurement has never been done, then the $\mathrm{SCr}$ at hospital admission is used, and the AKI is presumed to

Table 1. The diagnostic criteria of acute kidney injury in cirrhosis

\begin{tabular}{|c|c|}
\hline Parameter & Definition \\
\hline \multirow[t]{3}{*}{ Baseline SCr } & Stable SCr $\leq 3$ months \\
\hline & If not available, a stable SCr closest to the current one \\
\hline & If no previous $\mathrm{SCr}$ at all, use admission $\mathrm{SCr}$ \\
\hline Definition of AKI & $\uparrow$ in $\mathrm{SCr} \geq 26.5 \mu \mathrm{moL} / \mathrm{L}(0.3 \mathrm{mg} / \mathrm{dL}) \leq 48$ hours, or $\uparrow 50 \%$ from baseline \\
\hline \multirow[t]{3}{*}{ Staging } & Stage $1: \uparrow S C r \geq 26.4 \mu \mathrm{moL} / \mathrm{L}(0.3 \mathrm{mg} / \mathrm{dL})$ or $\uparrow \mathrm{SCr} \geq 1.5-2.0 \times$ from baseline \\
\hline & Stage $2: \uparrow \mathrm{SCr}>2.0-3.0 \times$ from baseline \\
\hline & $\begin{array}{l}\text { Stage } 3: \uparrow \mathrm{SCr}>3.0 \times \text { from baseline, or } \\
\mathrm{SCr} \geq 352 \mu \mathrm{moL} / \mathrm{L}(4.0 \mathrm{mg} / \mathrm{dL}) \text { with an acute } \uparrow \text { of } \geq 26.4 \mu \mathrm{moL} / \mathrm{L}(0.3 \mathrm{mg} / \mathrm{dL}) \text {, or } \\
\text { Initiation of renal replacement therapy }\end{array}$ \\
\hline
\end{tabular}

$\mathrm{SCr}$, Serum creatinine; AKI, acute kidney injury. 
have occurred in the past 7 days. The AKI episode can be classified into various stages depending on the severity, as in the other systems of AKI definition used by the nephrology community. This was felt to be important, especially since the severity of the AKI episode may have an impact on prognosis. ${ }^{13}$ Table 1, 2 describes the various stages of AKI. Progression of AKI is upgrading to the higher stage, whereas regression of AKI is downgrading to a lower stage (Table 2). The most severe form of AKI is hepatorenal syndrome (HRS). It is now defined as stage 2 or 3 AKI that fulfils all the other diagnostic criteria of $\mathrm{HRS}^{3}{ }^{3}$ but without setting a threshold of $\mathrm{SCr}$ for its diagnosis.

It is important to note that AKI does not only represent functional renal failure related to hemodynamic abnormalities in cirrhosis. Rather, the definition encompasses a spectrum of renal diseases that can cause acute renal dysfunction including structural renal diseases. ${ }^{14}$

\section{APPLICABILITY}

Even before the IAC formally defined AKI for cirrhosis, many investigators were applying the various other AKI definitions to evaluate whether these definitions could determine the prognosis of cirrhosis with renal dysfunction. ${ }^{15,16}$ All reported a higher baseline $\mathrm{SCr}$ in patients who developed AKI was associated with a significant increase in mortality. ${ }^{15,16}$ This was associated with a further rise in mortality in parallel with increasing severity of the AKI episode.

When applying the initial IAC and ADQI diagnostic criteria of AKI to a cohort of stable cirrhotic outpatients decompensated with ascites, the development of AKI was followed by a graduate increase in the $\mathrm{SCr}$ over a 12-month follow-up period, despite recovery from the initial AKI episode, associated with a significantly decreased survival. ${ }^{17}$ When the same criteria were applied to a cohort of hospitalized patients with infection, the development of AKI was associated with an 80\% 30-day mor- tality if there was no reversal of the AKI. Even for those patients who recovered from their AKI episodes, their 30-day mortality of $15 \%$ was still significantly higher when compared to $7 \%$ in patients who never developed AKI. ${ }^{18}$

The forgoing studies did not evaluate the impact of staging on patient outcome. However, progression of AKI during hospital stay occurs commonly. In a prospective study assessing the prognosis of 192 cirrhotic patients admitted into hospital with $\mathrm{AKI}_{1}^{13}$ there was a significant correlation between the initial AKI stage and in-hospital mortality. In addition, $44 \%$ of patients developed progression of their AKI, associated with more medical and cirrhosis related complications, together with a marked increase in mortality. Similar findings were also reported in another cohort of prospectively enrolled patients with the highest all-cause mortality being observed in patients with stage $3 \mathrm{AKI}$ on admission. ${ }^{15}$

Since the IAC diagnostic criteria for AKI in cirrhosis were published in early 2015, there has been only one publication that has applied the new diagnostic criteria to cirrhotic patients with AKI. ${ }^{19}$ A prevalence of $39 \%$ for AKI occurrence was observed, with almost half of the AKI episodes being at stage 1, irrespective of whether the lowest $\mathrm{SCr}$ in the previous 3 months or the closest pre-admission $\mathrm{SCr}$ was used as the baseline $\mathrm{SC}$, suggesting that the IAC proposed definition of the baseline $\mathrm{SCr}$ is valid. The 90 -day mortality was proportional to the initial AKI stage. For patients who did not recover from their AKI, their hazard ratio for mortality at 6 and 12 months were 6.3 and 4.6, respectively. Even for patients who recovered from their AKI episode, there was still a significant increase in mortality by 2 fold. For patients with stage $1 \mathrm{AKI}$ whose maximum $\mathrm{SCr}$ was $<1.5 \mathrm{mg} / \mathrm{dL}(133 \mu \mathrm{moL} / \mathrm{L})$, there was also a 3.5 fold increase in hazard ratio for mortality at 30 days. All of these findings confirm previous studies ${ }^{13-17}$ documenting that $\mathrm{AKI}$ in cirrhosis, even with trivial $\mathrm{SCr}$ changes, is detrimental to patient outcomes. Table 3 summarizes findings of recent studies on AKI in cirrhosis.

Table 2. Definition of progression of AKl and response to treatment

\begin{tabular}{|c|c|}
\hline Parameter & Definition \\
\hline Progression & Progression of AKI to a higher stage, or Need for renal replacement therapy \\
\hline Regression & Regression of AKI to a lower stage \\
\hline Response to treatment & $\begin{array}{l}\text { None : No regression of AKI } \\
\text { Partial : Regression of AKI stage with a } \downarrow \text { in } \mathrm{SCr} \text { to a value } \leq 0.3 \mathrm{mg} / \mathrm{dL} \text { adove baseline } \\
\text { Complete: } \downarrow \mathrm{SCr}<0.3 \mathrm{mg} / \mathrm{dL} \text { from baseline }\end{array}$ \\
\hline
\end{tabular}

AKI, acute kidney injury; SCr, Serum creatinine.

Reproduced from Angeli et al. ${ }^{12}$ 
Table 3. Recent studies on AKI in cirrhosis

\begin{tabular}{|c|c|c|c|c|}
\hline $\begin{array}{l}\text { First author } \\
\text { (publication } \\
\text { year) }\end{array}$ & $\begin{array}{c}\text { Patient } \\
\text { population }\end{array}$ & Type of study & $\begin{array}{l}\text { Diagnostic } \\
\text { criteria }\end{array}$ & Major findings \\
\hline $\begin{array}{l}\text { Warner et al. } \\
\text { (2011) }\end{array}$ & $\begin{array}{l}\text { Admitted cirrhotic } \\
\text { patients with ascites } \\
\& \mathrm{SCr}>1.5 \mathrm{mg} / \mathrm{dL}\end{array}$ & Retrospective & $\begin{array}{c}\text { AKIN \& } \\
\text { traditional }\end{array}$ & $\begin{array}{l}\mathrm{N}=152 \\
\text { Prevalence of AKI: } 70 \% \\
\text { AKI plus CKD: } 17 \% \\
\text { Pre-renal azotemia: } 69 \% \text { of all AKI } \\
\text { HRS-1: } 9 \% \\
\text { Hospital mortality for AKI: } 34 \%\end{array}$ \\
\hline $\begin{array}{l}\text { de Carvalho et } \\
\text { al. }^{28}(2012)\end{array}$ & $\begin{array}{l}\text { Admitted cirrhotic } \\
\text { patients with ascites }\end{array}$ & Retrospective & AKIN & $\begin{array}{l}\mathrm{N}=198 \\
\text { Prevalence of AKI: } 41 \% \\
\text { Hazard ratio for in-hospital mortality is } 2.6\end{array}$ \\
\hline $\begin{array}{l}\text { Altamirano et al. }{ }^{15} \\
\text { (2012) }\end{array}$ & $\begin{array}{l}\text { Admitted patients } \\
\text { with alcoholic } \\
\text { hepatitis }\end{array}$ & Retrospective & AKIN & $\begin{array}{l}\mathrm{N}=103 \\
\text { Prevalence of AKI: } 28 \% \\
90 \text { day mortality in AKI patients } 65 \% \text { vs. } 7 \% \text { in non-AKI patients }\end{array}$ \\
\hline Tsien et al." (2013) & $\begin{array}{l}\text { Stable cirrhotic } \\
\text { outpatients with } \\
\text { ascites }\end{array}$ & Prospective & $|A C \& A D Q|$ & $\begin{array}{l}\mathrm{N}=90 \\
\text { Prevalence of AKI: } 54 \% \\
30 \text { month survival was } 78 \% \text { in AKI group vs. } 93 \% \text { in non-AKI } \\
\text { group ( } P=0.049)\end{array}$ \\
\hline $\begin{array}{l}\text { Belcher et al. }{ }^{13} \\
\text { (2013) }\end{array}$ & $\begin{array}{l}\text { Admitted cirrhotic } \\
\text { patients with ascites } \\
\text { and AKI }\end{array}$ & Prospective & AKIN & $\begin{array}{l}\mathrm{N}=198 \\
\text { Progression of AKI: } 44 \% \\
\text { Progression was associated with a marked increase in in- } \\
\quad \text { hospital mortality }\end{array}$ \\
\hline $\begin{array}{l}\text { Wong et al. } \\
\text { (2013) }\end{array}$ & $\begin{array}{l}\text { Admitted cirrhotic } \\
\text { patients with ascites } \\
\text { and infection }\end{array}$ & Prospective & $|A C \& A D Q|$ & $\begin{array}{l}\mathrm{N}=337 \\
\text { Prevalence of AKI: } 49 \% \\
\text { 30-day mortality for AKI non recovery: } 80 \% \text {; } \\
\text { for AKI recovery: } 15 \% \text {; } \\
\text { for non-AKI patients: } 7 \%\end{array}$ \\
\hline $\begin{array}{l}\text { Fagundes et al. }{ }^{29} \\
(2013)\end{array}$ & $\begin{array}{l}\text { Admitted cirrhotic } \\
\text { patients with } \\
\text { complications }\end{array}$ & Prospective & AKIN & $\begin{array}{l}\mathrm{N}=375 \\
\text { Prevalence of AKI: } 47 \% \\
\text { Stage } 1 \text { AKI: } 77 \% \text { of all AKI episodes } \\
\text { Stage 1a*: } 90 \text {-day survival same as non AKI patients } \\
\text { Gradual decrease in } 90 \text {-day survival with increasing AKI stage } \\
\text { starting from stage } 1 b^{* *}\end{array}$ \\
\hline $\begin{array}{l}\text { Piano et al. } \\
\text { (2013) }\end{array}$ & $\begin{array}{l}\text { Admitted cirrhotic } \\
\text { patients }\end{array}$ & Prospective & $\begin{array}{c}\text { AKIN \& } \\
\text { traditional }\end{array}$ & $\begin{array}{l}\mathrm{N}=233 \\
\text { Prevalence of AKI: } 26 \% \text { (AKIN criteria) or 12\% (traditional criteria) } \\
\text { Traditional criteria better at identifying patients at risk for } \\
\text { progression of AKI }\end{array}$ \\
\hline $\begin{array}{l}\text { Scott et al. } \\
(2013)\end{array}$ & $\begin{array}{l}\text { Admitted cirrhotic } \\
\text { patients with AKI }\end{array}$ & $\begin{array}{l}\text { Prospective } \\
\text { (patients) } \\
\text { Retrospective } \\
\text { (controls) }\end{array}$ & AKIN & $\begin{array}{l}\mathrm{N}=110 \text { (patients) } \mathrm{N}=52 \text { (controls) } \\
\text { Higher baseline } \mathrm{SCr} \text { in AKI patients } \\
\text { Increasing in-hospital mortality with increasing stage of AKI }\end{array}$ \\
\hline $\begin{array}{l}\text { Bucsics et al. }^{31} \\
\text { (2015) }\end{array}$ & $\begin{array}{l}\text { Cirrhotic patients with } \\
\text { ascites undergoing } \\
\text { large volume } \\
\text { paracentesis }\end{array}$ & Retrospective & $\begin{array}{l}\text { AKIN \& } \\
\text { modified AKIN } \\
\text { for cirrhosis } \\
\text { (AKI-1a \& } 1 b^{* *} \text { ) }\end{array}$ & $\begin{array}{l}\mathrm{N}=239 \text { ( } 90 \% \text { inpatients) } \\
\text { Prevalence of AKI: } 32.6 \% \text { (AKIN criteria) } \\
\text { Increasing 30-day mortality with increasing stage of AKI } \\
\text { Increased mortality also observed in patients with peak SCr } \\
<1.5 \mathrm{mg} / \mathrm{dL}\end{array}$ \\
\hline $\begin{array}{l}\text { Tandon et al. }{ }^{19} \\
\text { (2016) }\end{array}$ & $\begin{array}{l}\text { Admitted cirrhotic } \\
\text { patients }\end{array}$ & Retrospective & IAC (2015) & $\begin{array}{l}\mathrm{N}=8,680 \\
\text { Prevalence of AKI: } 39 \% \\
\text { Increasing } 30 \text {-day mortality with increasing stage of AKI } \\
3.5 \text { fold increased in mortality also observed in patients with } \\
\text { peak } \mathrm{SCr}<1.5 \mathrm{mg} / \mathrm{dL}\end{array}$ \\
\hline
\end{tabular}

ADQI, Acute Dialysis Quality Initiative; AKI, Acute kidney injury; AKI-1a*, stage 1 AKI according to AKIN diagnostic criteria with the final serum creatinine $<1.5 \mathrm{mg} / \mathrm{dL} ;$ AKI-b**, stage 1 AKI according to AKIN diagnostic criteria with the final serum creatinine $\geq 1.5 \mathrm{mg} / \mathrm{dL}$; AKIN, Acute Kidney Injury Network; CKD, chronic kidney disease; HRS-1, type 1 hepatorenal syndrome; IAC, International Ascites Club; SCr, serum creatinine. 


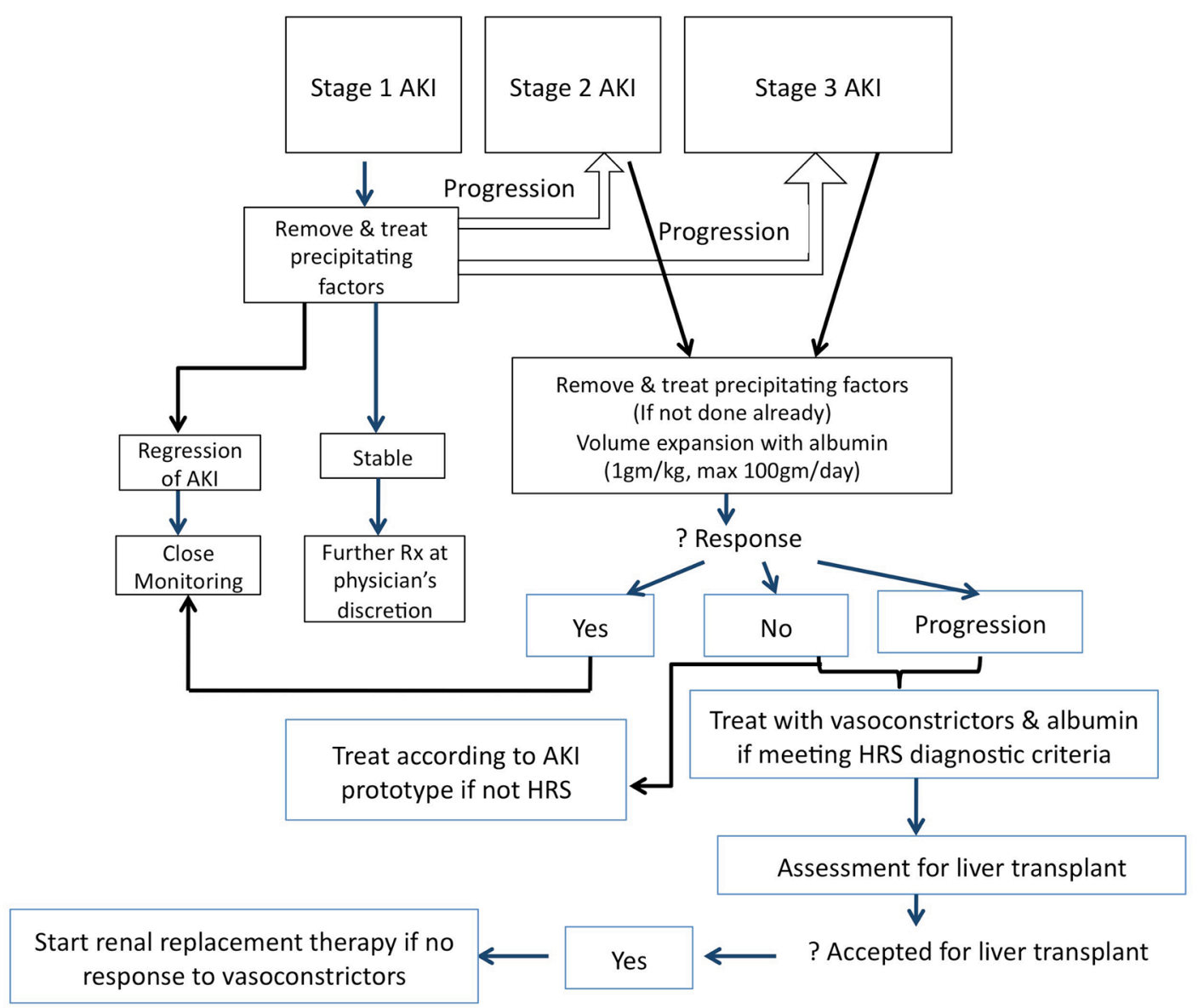

Figure 1. Suggested treatment algorithm for cirrhotic patients with acute kidney injury. AKI, acute kidney injury; HRS, hepatorenal syndrome; Rx, treatment.

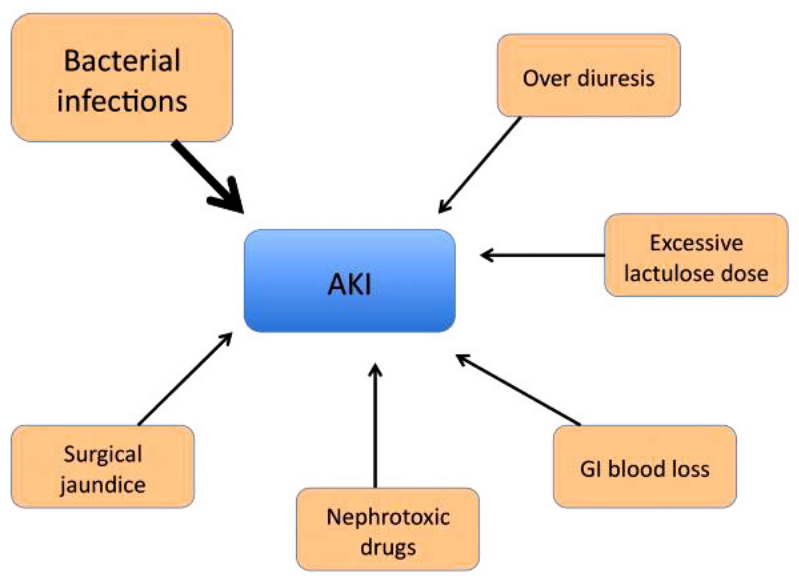

Figure 2. Precipitating factors for acute kidney injury. AKl, acute kidney injury; Gl, gastrointestinal.

\section{MANAGEMENT OF AKI}

The management of AKI should focus on early recognition and intervention. Figure 1 sets forth the proposed treatment algorithm for the management of AKI in cirrhosis. As the majority of AKI episodes are precipitated by an acute event (Fig. 2), which further exaggerates the already disturbed hemodynamics in advanced cirrhosis, it is imperative that all precipitating factors are identified and corrected. For patients who have become dehydrated from over-diuresis, or from excess lactulose use, the diuretics will have to be withdrawn or the lactulose dose reduced. For patients who have gastrointestinal bleeding, blood transfusion is needed to restore blood volume. All nephrotoxic drugs such as non-steroid anti-inflammatory agents or radiological dye need to be discontinued. Bacterial infections are the most common precipitant of renal dysfunction in cirrhosis. Bacterial products themselves can induce the produc- 
tion of inflammatory cytokines; many of these can disturb the glomerular microcirculation, or directly cause tubular cell death, leading to $\mathrm{AKI}^{20}{ }^{20}$ Therefore, it is important that all patients with AKI should undergo a full septic work-up and be started on empirical antibiotics. Albumin should be given at a dose of $1 \mathrm{~g} / \mathrm{kg}$ of body weight to a maximum of $100 \mathrm{~g} .{ }^{3}$ Apart from its volume expanding property, albumin also has scavenging, anti-oxidant and endothelial stabilizing functions, and therefore, can help to remove some of the inflammatory markers and excess vasodilators that are contributing to the pathogenesis of AKI. ${ }^{21}$ All of these measures should lead to a reversal of the AKI in the majority of patients. Even after AKI reversal, these patients need to be monitored regularly for the recurrence of AKI. For those patients who do not respond to these general measures, every attempt should be made to identify the cause of the AKI and treat accordingly. ${ }^{12}$

For patients who have stage 2 or 3 AKI, in addition to administering the same general measures, patients need to be assessed for the presence of HRS. Once HRS is diagnosed after excluding structural renal diseases, patients should be offered vasoconstrictor therapy, and continuation of albumin infusions. It has been shown that patients whose $\mathrm{SCr}$ does not reach the threshold of $1.5 \mathrm{mg} / \mathrm{dL}$ (133 $\mu \mathrm{moL} / \mathrm{L})$, but who otherwise fulfil the diagnostic criteria of HRS, have the same negative prognosis as patients who have HRS diagnosed using the traditional criteria. ${ }^{22}$ Patients should be assessed for liver transplant simultaneously. For patients who are accepted for liver transplant but do not respond to vasoconstrictor therapy, renal replacement therapy should be started as a bridging therapy. Otherwise renal replacement therapy has no role in the management of AKI in cirrhosis.

\section{EVOLVING CONCEPT OF AKI AND THE ROLE OF BIOMARKERS}

Given the fact that the current available tools for the diagnosis of AKI are imperfect, both in terms of an early diagnosis of $A K I$ and in differentiating between functional from structural causes of AKI, many investigators have explored the use of various biomarkers. A biomarker is a characteristic of a condition that can be objectively measured and evaluated as an indicator of biological function, or pathological processes, or a response to pharmacological interventions. Biomarkers can be identified in body fluids as well as in tissue specimens. Serum creatinine is a biomarker, but it limitations as a biomarker of renal dysfunction in cirrhosis are well documented. The advent of new technologies in cellular and molecular biology is now making the search for novel biomarkers possible. Biomarkers of renal dysfunction should not be measurable in the absence of AKI. An increase in the concentration of these biomarkers should alert one to the development of renal dysfunction. In general, the use of more than 1 biomarker will yield more accurate results. Several biomarkers have been studied in cirrhosis. Cystatin $C$ is a protein that is constantly produced by all nucleated cells and almost exclusively eliminated by glomerular filtration. Unlike SCr, serum cystatin C is not influenced by age, muscle mass, inflammation, or malignancy, nor is its measurement affected by the presence of high bilirubin. Various studies have shown that equations combining serum cystatin $\mathrm{C}$ and $\mathrm{SCr}$ may predict glomerular filtration better than those using $\mathrm{SCr}$ alone, especially when the glomerular filtration is below $60 \mathrm{~mL} / \mathrm{min}^{23}$ Other biomarkers have also been identified as being able to phenotype the AKI, separating functional renal failure from acute tubular necrosis (ATN). Examples of these are proteinuria of $>500 \mathrm{mg} /$ day, fractional excretion of filtered sodium or filtered urea. Other more novel biomarkers that can phenotype the AKI include neutrophil gelatinase-associated lipocalin (NGAL), interleukin 18 (IL-18), kidney injury marker-1 (KIM-1) and liver type fatty acid binding protein (L-FABP). ${ }^{24}$ All of these newer biomarkers show increased levels when there is renal injury, potentially indicating structural renal disease rather than functional renal failure. In a study that involved 188 patients with cirrhosis and $A K I$, urine samples were assessed to measure the levels of NGAL, IL-18, KIM-1 and L-FABP, as well as urinary albumin, and fractional excretion of sodium. ${ }^{25}$ The authors found that patients with ATN were more likely to have high levels of multiple biomarkers, whereas the majority of patients with pre-renal azotemia did not have detectable levels of biomarkers of kidney injury. The use of biomarkers in differentiating the different types of AKI will still need to be validated in larger clinical trials. The use of biomarkers in assisting the diagnosis of AKI will become clearer when we have a better understanding of the role of these molecules in the pathogenesis of AKI.

It is important to note that the biomarkers of AKI today may not be the biomarkers of AKI tomorrow. As AKI may evolve from pre-renal azotemia to HRS, and from HRS to ATN in the same patient, biomarkers will also have to evolve with the clinical condition. The future may provide biomarkers that can 
identify patients at risk for AKI, or biomarkers that can specify the mechanism of injury, or biomarkers that can indicate progression of AKI, so that clinicians can improve their ability to make the initial diagnosis, differential diagnoses, and track progression of disease and ultimately provide a clearer prognosis for the patients. ${ }^{26}$ Future diagnosis of AKI may include both functional and damage parameters.

\section{CONCLUSION}

The diagnosis of $A K I$ in cirrhosis has undergone dramatic changes in recent years, partly related to better understanding of the pathophysiology of AKI, and partly related to the need to institute earlier treatment, so to improve the prognosis of these patients. The IAC proposed changes in the definition and diagnostic criteria for AKI in cirrhosis is the first step towards better identification of these patients. Once validated, these diagnostic criteria will help to contribute to an improved prognosis of these patients. The use of biomarkers in the future will certainly further enhance the diagnostic accuracy of AKI for the patients.

\section{Conflicts of Interest}

The author is receiving grant support from Mallinckrodt Pharmaceuticals.

\section{REFERENCES}

1. Wong F. Recent advances in our understanding of hepatorenal syndrome. Nat Rev Gastroenterol Hepatol 2012;9:382-391.

2. Low G, Alexander GJ, Lomas DJ. Renal impairment in cirrhosis unrelated to hepatorenal syndrome. Can J Gastroenterol Hepatol 2015;29:253-257.

3. Salerno F, Gerbes A, Ginès $P$, Wong F, Arroyo V. Diagnosis, prevention and treatment of hepatorenal syndrome in cirrhosis. Gut 2007:56:1310-1318

4. Martín-Llahí M, Guevara M, Torre A, Fagundes C, Restuccia T, Gilabert $R$, et al. Prognostic importance of the cause of renal failure in patients with cirrhosis. Gastroenterology 2011;140:488-496.

5. Ruiz-del-Arbol L, Urman J, Fernández J, González M, Navasa M, Monescillo A, et al. Systemic, renal, and hepatic hemodynamic derangement in cirrhotic patients with spontaneous bacterial peritonitis. Hepatology 2003;38:1210-1218.

6. Francoz C, Glotz D, Moreau R, Durand F. The evaluation of renal function and disease in patients with cirrhosis. J Hepatol
2010;52:605-613.

7. Lassnigg A, Schmidlin D, Mouhieddine M, Bachmann LM, Druml W, Bauer $P$, et al. Minimal changes of serum creatinine predict prognosis in patients after cardiothoracic surgery: a prospective cohort study. J Am Soc Nephrol 2004;15:1597-1605.

8. Bellomo R, Ronco C, Kellum JA, Mehta RL, Palevsky P; Acute Dialysis Quality Initiative workgroup. Acute renal failure - definition, outcome measures, animal models, fluid therapy and information technology needs: the Second International Consensus Conference of the Acute Dialysis Quality Initiative (ADQI) Group. Crit Care 2004;8:R204-R212.

9. Mehta RL, Kellum JA, Shah SV, Molitoris BA, Ronco C, Warnock DG, et al. Acute Kidney Injury Network: report of an initiative to improve outcomes in acute kidney injury. Crit Care 2007;11:R31.

10. Kidney Disease: Improving Global Outcomes (KDIGO) Acute Kidney Injury Work Group. KDIGO Clinical Practice Guideline for Acute Kidney Injury. Kidney Int 2012;2(Suppl 1):1-138.

11. Wong F, Nadim MK, Kellum JA, Salerno F, Bellomo R, Gerbes A, et al. Working Party proposal for a revised classification system of renal dysfunction in patients with cirrhosis. Gut 2011;60:702-709.

12. Angeli $P$, Gines $P$, Wong F, Bernardi M, Boyer TD, Gerbes $A$, et al. Diagnosis and management of acute kidney injury in patients with cirrhosis: revised consensus recommendations of the International Club of Ascites. Gut 2015;64:531-537.

13. Belcher JM, Garcia-Tsao G, Sanyal AJ, Bhogal H, Lim JK, Ansari N, et al. Association of AKI with mortality and complications in hospitalized patients with cirrhosis. Hepatology 2013;57:753-762.

14. Trawalé JM, Paradis V, Rautou PE, Francoz C, Escolano S, Sallee M, et al. The spectrum of renal lesions in patients with cirrhosis: a clinicopathological study. Liver Int 2010;30:725-732.

15. Altamirano J, Fagundes C, Dominguez M, García E, Michelena J, Cárdenas $A$, et al. Acute kidney injury is an early predictor of mortality for patients with alcoholic hepatitis. Clin Gastroenterol Hepatol 2012;10:65-71.

16. Scott RA, Austin AS, Kolhe NV, McIntyre CW, Selb NM. Acute kidney injury is independently associated with death in patients with cirrhosis. Frontline Gastroenterol 2013;4:191-197.

17. Tsien $C D$, Rabie $R$, Wong F. Acute kidney injury in decompensated cirrhosis. Gut 2013;62:131-137.

18. Wong F, O'Leary JG, Reddy KR, Patton $H$, Kamath PS, Fallon MB, et al. New consensus definition for acute kidney injury accurately predicts 30-day mortality in cirrhosis with infection. Gastroenterology 2013;145:1280-1288. e1.

19. Tandon P, James MT, Abraldes JG, Karvellas CJ, Ye F, Pannu N. Relevance of new definitions to incidence and prognosis of acute kidney injury in hospitalized patients with cirrhosis: A retrospective population-based cohort study. PLoS One 2016;11:e0160394.

20. Gomez H, Ince C, De Backer D, Pickkers P, Payen D, Hotchkiss J, et 
al. A unified theory of sepsis-induced acute kidney injury: inflammation, microcirculatory dysfunction, bioenergetics, and the tubular cell adaptation to injury. Shock 2014;41:3-11.

21. Bernardi M, Ricci CS, Zaccherini G. Role of human albumin in the management of complications of liver cirrhosis. J Clin Exp Hepatol 2014;4:302-311.

22. Salerno F, Cazzaniga M, Merli M, Spinzi G, Saibeni S, Salmi A, et al. Diagnosis, treatment and survival of patients with hepatorenal syndrome: a survey on daily medical practice. J Hepatol 2011;55:12411248.

23. Gerbes AL, Gulberg V, Bilzer M, Vogeser M. Evaluation of serum cystatin $C$ concentration as a marker of renal function in patients with cirrhosis of the liver. Gut 2002;50:106-110.

24. Francoz C, Nadim MK, Durand F. Kidney biomarkers in cirrhosis. J Hepatol 2016;65:809-824.

25. Belcher JM, Sanyal AJ, Peixoto AJ, Perazella MA, Lim J, ThiessenPhilbrook $\mathrm{H}$, et al. Kidney biomarkers and differential diagnosis of patients with cirrhosis and acute kidney injury. Hepatology 2014:60:622-632.

26. Murray PT, Mehta RL, Shaw A, Ronco C, Endre Z, Kellum JA, et al. Potential use of biomarkers in acute kidney injury: report and sum- mary of recommendations from the 10th Acute Dialysis Quality Initiative consensus conference. Kidney Int 2014;85:513-521.

27. Warner NS, Cuthbert JA, Bhore R, Rockey DC. Acute kidney injury and chronic kidney disease in hospitalized patients with cirrhosis. J Investig Med 2011;59:1244-1251.

28. de Carvalho JR, Villela-Nogueira CA, Luiz RR, Guzzo PL, da Silva Rosa JM, Rocha $E$, et al. Acute kidney injury network criteria as a predictor of hospital mortality in cirrhotic patients with ascites. J Clin Gastroenterol 2012;46:e21-e26.

29. Fagundes C, Barreto R, Guevara M, Garcia E, Solà E, Rodríguez E, et al. A modified acute kidney injury classification for diagnosis and risk stratification of impairment of kidney function in cirrhosis. J Hepatol 2013;59:474-481.

30. Piano S, Rosi S, Maresio G, Fasolato S, Cavallin M, Romano A, et al. Evaluation of the Acute Kidney Injury Network criteria in hospitalized patients with cirrhosis and ascites. J Hepatol 2013;59:482-489.

31. Bucsics T, Mandorfer M, Schwabl P, Bota S, Sieghart W, Ferlitsch A, et al. Impact of acute kidney injury on prognosis of patients with liver cirrhosis and ascites: A retrospective cohort study. J Gastroenterol Hepatol 2015;30:1657-1665. 